Relations industrielles

Industrial Relations

\title{
A Way of Thinking about Collective Bargaining: Circumstance, Policy, Law and Actuality
}

\section{A.W.R. Carrothers}

Volume 40, numéro 2, 1985

URI : https://id.erudit.org/iderudit/050138ar

DOI : https://doi.org/10.7202/050138ar

Aller au sommaire du numéro

Éditeur(s)

Département des relations industrielles de l'Université Laval

ISSN

0034-379X (imprimé)

1703-8138 (numérique)

Découvrir la revue

Citer cet article

Carrothers, A. (1985). A Way of Thinking about Collective Bargaining: Circumstance, Policy, Law and Actuality. Relations industrielles / Industrial

Relations, 40(2), 351-366. https://doi.org/10.7202/050138ar
Résumé de l'article

The object of this paper is to offer a taxonomy - a kind of classification System - as an aid to thinking, in a number of interrelated dimensions, about collective bargaining as a phenomenon of the relationship between management and labour.
Tous droits réservés @ C Département des relations industrielles de l'Universite Laval, 1985
Ce document est protégé par la loi sur le droit d'auteur. L’utilisation des services d'Érudit (y compris la reproduction) est assujettie à sa politique d'utilisation que vous pouvez consulter en ligne.

https://apropos.erudit.org/fr/usagers/politique-dutilisation/ 


\title{
A Way of Thinking about Collective Bargaining
}

\section{Circumstance, Policy, Law and Actuality}

\author{
A.W.R. Carrothers
}

The object of this paper is to offer a taxonomy - a kind of classification system - as an aid to thinking, in a number of interrelated dimensions, about collective bargaining as a phenomenon of the relationship between management and labour.

The paper is divided into four parts. The theme of Part One, «Circumstance», is that historically the peculiarities of the collective bargaining systems of industrialized democracies are the product of circumstance which gives a surface uniqueness to each system and informs the law and hence contributes to the configurations of thought and behaviour of the actors, of those who must relate to the institutions.

The theme of the second Part, "Policy», is that in all the systems reviewed in Part One there are six major freedoms competing for supremacy, differing in direction and magnitude and varying under the pressures of circumstantial and structural or systemic change, with the legal system producing a certain vector of rights and responsibilities.

The third Part, «Law», describes the principal options in designing a legal system for collective bargaining as a crucible for the policy choices described in Part Two, to identify the concepts of content, initiative, sources, processes, constituencies and participants.

The fourth Part, «Actuality», summarizes the factors, mainly economic and social, in a society which experience tells us have a high probability of helping to shape decisions relating to the development of an industrial relations system which collective bargaining encompasses.

The concluding paragraph returns to the theme of diversity of form and commonality of policy.

Inherent to the analysis are certain political assumptions in the expression industrialized democracies. The assumptions are not expounded, but

* CARROTHERS, A.W.R., Professor, Faculty of Law, University of Ottawa.

Relat. ind., vol. 40, no 2, 1985 ๑ PUL ISSN 0034-379 X 
may be stated here briefly to include the accommodation and practices of political pluralism, including a recognized opposition to the government of the day, loyal to democratic processes; free and regular elections by secret ballot founded on universal adult suffrage; a free press, freedom of speech, including the right of open dissent, and freedom of assembly, the right to protection against illegal imprisonment - habeas corpus; an independent judiciary; and the right and duty in a duly elected government to govern, within the principle of accountability.

The countries whose collective bargaining processes are reviewed in the text vary in respect of particular political, social and economic ideology and in the degree of politicization of the trade union movement and its relation to the state, characterizations which range on a continuum from «left» to «right». But the rights and freedoms help to mark the outer limits of that continuum. Free collective bargaining cannot be expected to exist without such a context.

\section{PART ONE - CIRCUMSTANCE}

\section{United Kingdom}

In the United Kingdom collective bargaining has its roots in the industrial revolution of the mid-eighteenth century. Land was being cleared of tenants to make way for more profitable land usage. People without useful skills were herded into overcrowded towns. The steam engine was rapidly replacing water power in newly developing factories demanding unskilled labour, of which there was by then an abundance. Craftsmen who theretofore supplied the skills of their trade, owned the modest capital with which they worked, possessed the talent required for their enterprise and managed the supply of the materials with which they worked, found themselves in possession of nothing but skills which machines were overtaking. To meet the demands of a new capitalism the joint stock company, the forerunner of the modern business corporation, was recovering from the disaster of the South Sea Bubble of 1720 to provide the base for the acquisition of new venture capital to provide the economic capacity to feed the new industrial revolution in England, in its growing overseas dependencies and in international trade. It was the Age of Individualism, which was to spark political revolutions in America and France and was to countenance global wars.

The labour force started to combine for mutual protection. The modern trade union movement was born. Employers, too, combined to form trade associations to regulate activities in their parts of the economy for their mutual benefit, as they had a century and a half earlier in the prototypical East India Company.

The government responded in the heat of the Napoleonic Wars with criminal legislation to put down combinations against the public interest. Economic imperatives protected entrepreneurs: they were needed. But for the labour movement the new legislation turned the nineteenth century into a struggle against the bad name of restraint of trade. The need was for 
legislative reform - for political solutions. When reforms came, in the second half of the century and before World War One, they left collective bargaining and trade unions for the most part outside the legal system. There was effectively no centralized legal system of collective bargaining. There was at most a minimal legal framework, and most activity within it was voluntary. The collective agreement had no legal status. Trade unions emerged independent minded and highly protective of their own affairs. The key to the «system» was the «shop steward movement», the institution of individual trade union officials on the plant floor. And the system grew within a class in a class-structured society which discouraged upward mobility. The political demands of an economic stratum locked into the social structure led to the creation of the Labour Party. In other countries the labour movement was the product of political institutions; in the United Kingdom it was the other way round.

\section{United States}

The American Civil War is seen by some historians as a struggle between the forces of economic expansionism in the north-eastern United States and the agricultural slave-oriented south. The years after the Civil War saw tremendous economic growth, and the rise of financial giants and industrial barons in stell and coal and railway construction. In the 1880's labour organized, blossomed and was crushed. The rebuilding of the labour movement was long and bloody, from the mills in the north-east to the mines and forests of the north-west. The industrial needs of World War One granted a protective pause which was followed in the 1920's by the counter-thrust of the company union. That was stood on its ear by New Deal legislation enacted in the name of national economic recovery during Franklin Roosevelt's first term as President. The Wagner Act of 1935 - the National Labor Relations Act - imposed a labour relations system on the nation.

The legislation set out to establish the right of employees to organize into independent trade unions, the right of unions to bargain with the employer over terms and conditions of employment, and the right to invoke meaningful economic sanctions where negotiations failed - the right, in effect, to strike. The system is legalistic. It is supervised by an administrative tribunal with power to make regulations and to hear disputes and make quasi-judicial decisions. To protect rights the law proscribes itemized unfair labour practices. It creates formal processes for recognizing a union as a bargaining agent. It declares a duty to bargain in good faith. There is statutory control over legal remedies, particularly over the labour injunction. The legislation provides for new remedies through labour board orders. And legislative rules give a dimension to the law of picketing and boycotting quite different from the perspective of the common law of «industrial torts».

In 1949 major changes were made to protect management rights and the interests of individuals. And in 1963 the law reached into the regulation of the internal affairs of unions.

\section{Canada}

In Canada there was little activity in the nineteenth century except for the introduction of legislative reforms developed in the United Kingdom. Until the beginning of World War Two over half the gross national product 
of the country derived from agriculture. Early 20 th century reforms stemmed from conflict in basic or extractive or primary industry and in transportation. Transportation and transportation disputes tell a great deal about Canada. The distance from the east coast of Canada to the west is greater than the distance from the east to France. Geographically Canada covers nearly five million square miles and has a population of less than 25 million. The bulk of the population lives along a vast water course within a hundred miles of the American border.

In the early years of the 20th century Canada developed the policy of postponing the right to strike, to form a cooling off period within which the government could, in the name of the public interest, send conciliators into a dispute. It amounted to legislative control of collective bargaining behaviour, and involved administrative intervention by the government. In this it anticipated the Wagner Act by three decades and provided a model for the regulation of railway labour disputes in the United States in the 1920 's. Matters then remained relatively dormant for nearly 40 years Canada was busy growing and surviving in other ways - until the closing years of World War Two. In 1944, through executive action by the central government, Canada received a full-blown legal framework for collective bargaining based on the US Wagner Act of 1935, with two important additions: work stoppages were prohibited by law during the term of a collective agreement, and disputes under the collective agreement were ultimately to be settled by arbitration. Thus at a single stroke the collective agreement became a legal instrument and the quasi-judicial process of arbitration became a major feature of its administration, along with the development of legal processes and substantive law and the development and improvisation of remedies. There was at once a law of labour relations as a major branch of administrative law for the regulation of economic behaviour for social purposes. Since that time Canada's greatest innovation has been the introduction of full collective bargaining into the public services. In distinction from the melting pot theory of the United States, Canada is built on the concept of two founding nations, the French and the English. In fact much of Canada outside the province of Québec is a melting pot and is becoming increasingly so. Upward mobility is largely a factor of education, which in turn is in a fair measure a matter of opportunity seized. The labour factor of production has yet to align itself with a political ideology. Canada is thus distinguishable in its labour relations context from the US and the United Kingdom. It has the most highly legalistic system of collective bargaining in the industrialized democratic world.

\section{Sweden}

The Swedish system of industrial relations is highly structured and highly centralized, with a strong central labour federation, a strong central management organization and a carefully defined role for the government in sustaining and maintaining the system and intervening in its operation. It is the product of a disastrous breakdown in industrial relations in the 1930 's. The system operates in a democratic socialist state. Sweden is a nation of a homogeneous people relatively accepting of authority, and committed to its social welfare programs and the sustaining administrative functions which such social action requires. Within that ambience the industrial relations system must make its own problematical trade-offs. 


\section{West Germany}

The most obvious manifestation of West Germany's industrial relations system is in its corporate structure. The German corporation has a two-tiered board of directors, with employee representation on the supervisory board. The system also sustains joint consultative councils which may provide in fact greater employee participation in management decisions than do the directorships. Shop floor activity as a form of participation in the system is much less significant. The system was imposed by the British forces of occupation after World War Two (the two-tier corporate model was known in Germany well before that time) in the coal and steel industry to forestall, through labour participation in the determination of industrial policy, a resurgence of national socialism. The system has spread to German industry at large and is on the verge of entering the United Kingdom through stipulations for corporate organization from the European Community.

One could continue with thumb nail sketches of other industrialized democracies: France, the Netherlands, Belgium, Australia, Japan. But the message is the same. In all these countries there have arisen issues of basic and derivative rights and freedoms, of conflicting interests and their reconciliation, which arose in unique ways, and have been resolved within the institutions of the law (the courts, the legislatures, the executive, through bargain and agreement) with varying degrees of satisfaction and for different spans of time.

\section{PART TWO - POLICY}

Collective bargaining, as a private sector phenomenon, is a mechanism for the redistribution of wealth generated by an enterprise, among the competing factors of production, through the price of «materials», the cost of «capital», the wages of «labour», and the profits of «enterprise». It is a stratagem by which the worker can in some measure participate in the determination of his economic destiny. It redistributes power and authority within the community of the work place. It provides a form of government with which priorities of interests may be reconciled. It is thus an instrument of industrial democracy. The argument is made that in a political democracy with a mixed enterprise system, where the stratagem of collective bargaining not at hand, the benefits deriving from it would be demanded of the state to the detriment of the enterprise system. Thus, collective bargaining may be viewed as a natural concomitant of private enterprise, of public enterprise and even of public service.

Collective bargaining is something more than an inevitable historical event in the economic development of a political democracy, to be managed accordingly. It claims the higher ground of conscious policy, to be understood, crafted with care, put in place, maintained, appraised and overhauled.

What are the components of collective bargaining as policy? 
In order to have an effective process of collective bargaining, a legal system must protect employees in three principal areas of activity: first, in forming themselves into a functional collectivity conventionally called a trade union; second, in securing from the employer a relationship of effective negotiation with a view to reaching agreement over terms and conditions of employment (in effect a mutual duty, and hence a reciprocal mutual right, to bargain in good faith); and third, in the event that negotiations fail, in invoking meaningful economic sanctions against the employer with a view to inducing agreement. Conventionally such sanctions consist of striking, that is, a collective withdrawal of services, and peaceful picketing, that is, the physical presence of persons at the work place advertising their position that the observer not do business with the employer (the boycott). Engaging in political activity to gain the same or similar objectives should not be overlooked, as students of the French and Italian scenes will confirm.

The first of these freedoms, the right to organize, can be defeated if the employer should engage in threats of harm or promises of reward to the individual employee to induce him to avoid union membership or to work against union organization. In North America after World War One employers created or supported company or plant unions as a plausible alternative to independent unions. But independence from the employer is a quality essential to a bargaining agent.

The establisment of the freedom of union organization presents an example of a series of policy choices. First is the selection of collective bargaining as national economic and social policy. Seçond is the recognition of the policy of independent unionism. Third is the policy choice of whether independent unions should develop extra-legally, as they did in the United Kingdom, or under the protection of the law, as they did in North America. That decision will in turn inform the substantive law.

It is an enormously important policy question whether and to what extent the collective bargaining system should be extra-legal; where it is intralegal, whether and to what extent it should be self-operative or be managed by a public authority; and, where there is to be a public agency, how that agency should be composed, what should be its jurisdiction, and how its function should relate to the courts and to the exercise of executive discretion. The theme of the selection of interdependent policies is inherent in the whole of this paper.

The second freedom is the right to collective bargaining proper. The vast bulk, and the best, of human relationships have at their core the element of consensus, of mutuality, of agreement, of common intent. Legal systems cannot compel people to agree. Nor have legal systems been prone to require people to bargain with a view to reaching an agreement. Trial judges have been known on occasion to persuade counsel to settle an awkward case, and labour arbitrators recognize a role of mediation as an adjunct of their quasi-judicial function. But the duty to bargain in good faith is not easy to define, bad faith bargaining is not easy to identify, and the role of legal sanctions is not easy to appraise. 
Once the policy choice is taken taht an employer has a duty to bargain in good faith, a series of derivate policy questions arises. With what union does the duty arise? What evidence should be required that the union has the support of the employees? If membership in the union is to be the test, should the union be free to define and determine membership or should the right to membership be prescribed by the law?

Let us assume that there has been established a bargaining nexus between a union and an employer, that they have bargained in good faith, and that they have reached an impasse. (Where the parties reach agreement the derivative policy question arises as to whether and how the resulting collective agreement is to be enforced and administered: what kind of standing, if any, the collective agreement is to have at law.)

The third freedom, the right to invoke meaningful economic sanctions, is easy to state and enormously complicated in its execution. It should be recognized that, except where both the supply of and demand for labour is inelastic, freedom of speech in the form of a capacity to persuade becomes a significant component in the effectiveness of economic sanctions. The right to strike involves matters of definition and declaration of right. If the right to strike does not preclude the employer from continuing its operations, the union will seek to close down the operations by persuading others not to take employment and not to do business with the employer or deal in the employer's product. The conventional means of persuasion has become the picket line, backed by the ethic that picket lines are not to be crossed. The object is the boycott. Assuming an absence of wrongful behaviour in the picketing activity, to whom should the union be free to address its message, against whom should it be free to address it, and where?

(1) to its members who have been called on strike?

(2) to other employees who are not members of the union?

(3) to employees who are members of another union?

(4) to persons wishing to do business with the employer?

(5) to persons who have been doing business with the employer and wish to continue?

(6) to suppliers of the employer?

(7) to purchasers of the employer's product?

(8) at the place of business of the supplier or the purchaser?

(9) at other plants of the employer?

(10) at plants of other employers in the industry who may or may not be servicing the needs of the employer's customers?

(11) at the operations of corporate subsidiaries of the employer?

(12) at private homes?

Should the response to the questions depend on:

(1) the merits of the dispute?

(2) the relative economic strength of the parties (a) at the time of the impasse or (b) in the course of the dispute? 
(3) the impact of the dispute, of its settlement, and of the terms of settlement on government policies at large?

(4) whether the public, as a collectivity of innocent and impotent bystanders (the question may be asked whether the public is ever entirely innocent or impotent), is directly prejudiced by the dispute?

(5) in what way, and in what degree, the public is prejudiced? strike?

What as a matter of policy should be the legitimacy of the general

Some of these questions may support a policy response simply as a matter of reflection. They have been arranged in a descending order of a probable affirmative answer. Others of these questions will support a policy response (what should be the extent of permissible conduct?) only following an appraisal of specific actualities in all their complexities.

In the United States, and more so in Canada, these questions have been the subject of a kind of codification, with a heavy gloss of case law, administrative decision and regulation, and ad hoc or discretionary legislation and executive action. The general area has been addressed recently by the United Kingdom Parliament, but the employer has been reluctant to take up the legal sword, such is the antipathy in that country to legalism in industrial relations.

Can there be collective bargaining without the right to strike? It is argued that if strikes are made illegal all that that will produce is illegal strikes. It is argued further that where the public interest in the delivery of goods and services overrides the public interest in collective bargaining, those who are charged with imposing a solution must have access to relevant information derived from a relatively free market of which free collective bargaining is a component. In the United States the right to strike is, with few exceptions, denied to the public service. In the United Kingdom there is a quasi-judicial system that keeps terms of public service employment relatively sweet. In Canada there is a right to strike in the federal public service with substantial constraints to protect the performance of essential services. Ad hoc legislation to terminate lawful strikes in the public interest is prevalent in Canada. It is virtually unknown in the United Kingdom and the United States.

If the right to strike is to be denied, what is to take its place to resolve an impasse? The procedure most often used is the quasi-judicial process of arbitration, but a settlement imposed by executive action is not out of the question. It is a policy choice.

The three basic freedoms of collective bargaining involve an obligation in others not to interfere with those freedoms. Yet others have claims of their own which compete with those freedoms and mark their limits. The patrolling of the shifting interface of competing rights and freedoms is the hard and continuing task of the politico-legal system, for freedoms are not absolute. They cannot be and coexist.

There are two freedoms which compete with the collective bargaining trilogy of employee collectivities which demand special attention. The first is the right of the individual employee to work. The second is the right of the employer to manage. 
In any organization the interests of the individual must be subservient to the interests of the collectivity to the extent necessary for the pursuit of its objectives. The individual surrenders his freedom in one direction in order to gain benefits in another.

Where the individual has a choice and opts out, he cannot be heard to complain. Where he opts in, he has acquired something of value which the law might be concerned to protect. Where the individual has no choice but to join an organization, the law ought to be concerned to protect his access and his continuing membership.

A trade union is such a collectivity. A union is bound to seek security of employment for its members. It will bargain for it. It will seek to protect its present members who are employees and its members who are unemployed or may become unemployed. It will seek to make membership in the union a condition prior to taking employment, and as a condition of continuing in employment. Obviously access to membership and continuation in membership is of overwhelming interest to the employee. The individual will therefore assert from the law the right of access to membership and to participation according to the rules of the union, and the right to fair rules.

In 1851 Sir Henry Maine in his book Ancient Law observed that the development of the individual in a progressive legal system marked a growth from status to contract. The position of the individual worker in a modern industrial society has taken on fundamental characteristics of status. He can make no separate agreement with his employer. He has no personal right to be present at the bargaining table. If he enters into employment after the bargaining is over, he has no vote on the terms of the collective agreement. He has no right of access to the administration of the collective agreement. If he has a personal grievance against his employer he is dependent on the decision of the trade union whether to process his case. His contract of employment is thus largely nominal, and is controlled by externalities. If I am right in an earlier statement that the bulk and the best of human relationships are at their core consensual, the contract of union membership can be the lifeline of the individual to the best of human relationships as they relate to the work place, to his sense of worth and to his sense of personality.

The protection of the right to work as against the union involves such policy questions as to whether the law should regulate union security clauses so as to protect the individual where he has been denied union membership; whether the law should prescribe minimum protective provisions in union constitutions, as it does for «members» in the constitutions of public business corporations; and whether the law should impose fair processes on a union's internal affairs, not as a matter of agreement (on the theory that such processes are implicit in the contract of membership), but as a matter of policy and therefore of law.

I come now to the fifth on my list of the freedoms to be accommodated in a collective bargaining system, the freedom of the employer to manage.

Just as employees may need protection from an employer's efforts to impede free trade unionism, so may an employer need protection from a 
union's importunities against it. If the law embarks upon a recitation of a code of employer improper behaviour, it will be hard pressed not to recite prohibited behaviour by unions and employees. The employer's best protection is his own freedom of speech, and his freedom of assembly into employers' associations.

The list of competing rights, freedoms and interests does not stop there. The public, in the sense of collectivity of private citizens, has a claim to access to goods and services. The public, as the totality of its citizens, has an overriding claim that the government must govern. Collective bargaining is not an «extra-parliamentary process».

\section{PART THREE - LAW}

When the policy choices outlined in the preceding Part, and their kinfolk, have been determined, within the sustaining political fabric, the law emerges as a melange of individual and collective rights, duties, powers, liabilities, immunities, and remedies, which must be rendered into operable rules, within choices of structures, sources and processes.

A useful starting point in perceivirg choices in legal systems is to note the distinction between a system in which the citizen is responsible for commencing legal proceedings for the protection of his rights and carrying that initiative to a conclusion, and a system in which a public mechanism is provided for initiating, overseeing and completing the process. The first may be characterized as self-operative, the second as administered. The first is particularly suited to the protection of individual private rights, where the decision whether to invoke he law as one of many social instruments for channelling behaviour is best taken by the person who considers his rights to be in need of that kind of protection. Examples are private rights of the person (including personality) and of property (including economic activity). The second kind of system is of service where the public interest goes beyond ensuring that legal mechanisms are available to the individual, to active involvement in the protection of rights and in the security of the legal system itself, and therefore justifies the existence of a public strategem of law enforcement. An obvious example is the administration of criminal justice (where, it should be noted, scope is retained for private initiative as well). For present purposes a perhaps less obvious but more pertinent example is that of a labour relations board, as the custodian of the public interest in the maintenance of a labour-management system within which individual and collective rights are to be preserved.

The operation of the first kind of system is heavily (but not exclusively) dependent on the resources, and the resourcefulness, of the individual citizen; the second kind is dependent on the creation and maintenance of an administrative structure to implement, execute and monitor the system.

In the United Kingdom, as described in Part Two, the system is not so very «public» in philosophy - the "public policy» is to keep the system «extra-legal». In the United States, as in Canada, the policy is to assert the public interest in the protection of rights and the resolution of conflict. That policy choice leads to the creation of instruments of the state to oversee and 
execute the policy. In addition to initiatives that may be taken by the individual, the state has a positive presence in the protection of what, up to that point, might be regarded as private interests (for example, the right of the individual to associate with others). What the instrument can do depends on what the state equips it to do.

What are the sources of the law that sustain the rights and duties of a collective bargaining system? They can be bargain and agreement; legislation; judge-made law, in the form of common law or as a gloss on a civil code or on statutes; administrative regulation; and decisions of private or statutory arbitrators.

One would expect a dominant source of rights in a collective bargaining system to be the instrument that is the product of the collective bargaining process, the collective agreement. It can be the most primitive expression of accord settled on a simple handshake or other symbol a meeting of minds. It can be a complex written instrument reaching into every corner of life in the workplace. The fact that it is an agreement means that the contents are determined by the parties themselves, that the act of creation is an act of mutual consent, not of imposition. That gives bargain the potential of infinite variety which makes the agreement unique as a source of rights crafted to the needs and priorities of the parties by the parties themselves. As a source of rights it is not unlimited, but it is the least limited. If it is not what the parties want, it is the best they can get from each other. Among the countries referred to earlier, historically the collective agreement has ranged from a document of no legal significance whatever to a highly regulated and rigidly enforceable prescription of rights and obligations.

A second source of rights is legislation. Parliament may prescribe a framework of substantive and procedural rights and duties, and may prescribe limitations on the freedom of the parties to negotiate their own terms, with a view to protecting interests claiming public protection that might otherwise be overlooked. The legislative response may range from a decision to do nothing, through a simple enabling statute, to a complex prescriptive regulation of the collective bargaining phenomenon.

A third source of law is the decisions of courts expounding principles of common law or providing a gloss on a code or a statute or a constitution. It is a process of case by case accretion to an understanding of rights, an exposition of the law through specific problem solving. It is the judicial process of lawmaking, bounded by procedures designed to meet the tests, not always successfully, of fairness and efficacy. It can take place by the light of a campfire as validly as in an atmosphere rich in metaphor and ceremony.

Where the legislature creates an administrative body to receive delegated power to regulate behaviour, its rules become an important source of legal rights. Unlike the legislature, which normally limits itself to declaring rights, unlike the courts, which limit themselves to pronouncing on rights in particular situations of conflict brought forth by parties of interest, and unlike an enforcement agency which is concerned with seeing that matters of rights and wrongs are brought to adjudication, the administrative tribunal may be and usually is charged with performing all three functions. 
Its justification arises where the legislature determines that public policy requires an instrument of social policy that can respond with comparative speed, knowledge and specialized manpower to a need for the application of the social policy.

The countries cited above provide examples ranging from an almost total absence of intervention to a highly intrusive scheme for the prescription of rules, the investigation of conflict and the adjudication of disputes by an administrative tribunal. It depends on what kind of system one wants, or what kind of system is generated by the circumstances of history and the actualities of response to conflict. Whatever the total response, it becomes part of a specific legal system.

At some point in their development the collective bargaining systems of the industrialized democracies have invoked the aid of systems of ad hoc adjudication either as a matter of private arrangement or as a matter of statutory imposition. Sometimes the schemes themselves have been ad hoc; sometimes the device is in place as a matter of policy and it is the act of adjudication that is ad hoc. In either event, the adjudication is a quasi-judicial process, constrained by basic rules of procedural fairness, with the decison binding the parties. It has much of the potential variety of the process of bargain and consent that creates the collective agreement, for it is often the rights contained in the collective agreement that are the subject of adjudication. It can be as pervasive and creative in its processes, declarations and remedies as the collective agreement itself is in its prescription of rights and obligations. And it need be available only on demand.

The details of the processes of the law are in large measure shaped by their sources. Two broad philosophies of process may be identified: the adversarial and the inquisitorial. Under the adversarial system parties in conflict bring their dispute to the tribunal and make partisan presentations, after which, and presumably on the strength or merits of which, the tribunal reaches a conclusion. Under the inquisitorial model the tribunal (or officers acting on its behalf) accepts responsibility for investigating the dispute and informing thereby the judgment of the tribunal. In the first case the onus for proceeding is on the parties; in the second the onus falls much more heavily on the court and its officers. In the English speaking world the adversarial approach is found in the formal court system, whether civil or criminal. Administrative agencies in those same countries have important characteristics of inquisitorial techniques, the initiative of representations from the parties being complementary to the initiative of inquiry by the tribunal. In private arbitration two more dimensions may intrude: the search within the judicial process for a solution attracting the consent or the deference of the parties that preempts actual adjudication (that is, mediation and settlement by consent); and the crafting of remedies, within bounds, shaped to the demands of the private or quasi-private nature of the dispute.

In a system of collective bargaining that, as a matter of public policy, does not embrace the public law, the question of sources and processes of the law does not arise. At the other extreme a highly complex system can contain elements of all the sources and processes described above, and, by way of demonstration, in the United States and Canada it does so. 
The selection of policies and processes of the law may be influenced by the character of the economy in which the system is to operate, by the behavioural expectations of the parties, and by the nature and degree of the public interest in the resolution of conflict. Collective bargaining as public policy in agriculture may command a certain selection of legal policies and processes that may differ materially from what is adjudged to be appropriate for collective bargaining in basic industries such as mining, fishing, and forestry. Although they all are «extraction» industries, they present different employment profiles. The construction industry presents its own imperatives. Manufacturing has for most of the twentieth century been the flagship of collective bargaining policy, with its policies being adapted with varying degrees of success to the primary and tertiary sectors, including transportation, communications and education. The tertiary or service sector increasingly makes its own demands as the information industry shapes economic activity at large. The perception of the public interest in collective bargaining re-forms as the economy reshapes itself, and new choices of policy in all its aspects evolve.

Who are the contestants, the performers, the actors in the legal system? They are manifold. Obviously, in a collective bargaining system the most apparent are employers and unions. The employer may be an individual or a corporation, and in terms of economic strength - the power against which a union is a counterweight in the negotiation of terms under which economic activity is to proceed - the employer may range from the humblest enterprise to multinational corporations more powerful than state governments. The union may range from the smallest local to the largest federation. Governments at all levels participate in the determination and imposition of policy and frequently emerge as employers in their own right. Individual employees assert rights that bring unions into existence; at the same time they can have interests distinct from those of the collectivity and even in conflict with it. The same can be said of employers' associations. The voting public is a collectivity of private rights and powers; and as a totality the "public» is the personification of the state.

There are important actors at the international level in a domestic collective bargaining system: the International Labour Organization, with its conventions and declarations of policy and its processes for investigating complaints within particular states, in business more than twenty-five years before the Universal Declaration of Human Rights and the most significant survivor of international organizations created between the two World Wars; and the United Nations itself. Recognition should be given to the International Confederation of Free Trade Unions, and to international employers' associations. More recently, decisions of the European Court of Human Rights are having a direct impact on the domestic laws of member states and through them an indirect impact on the international community.

All these performers command their portion of attention in devising and applying a taxonomy for collective bargaining. 


\section{PART FOUR - ACTUALITIES}

There are fundamental questions of freedom that are common to the collective bargaining systems of all industrialized democracies. Although the policy questions incite much the same moral responses, the answers to the policy questions at the secondary or operational level are determined by circumstances and actuality where the choice is one less of morality than it is of feasibility and where legal answers may be comparatively short lived as improvements come to hand.

If there are lessons to be learned from history, one might ask what were the actualities of the day in the particular industrialized countries on whose experience this paper draws that constituted the forces entering into the social equation that produced the direction in which collective bargaining developed? What generalizations do they invite? What lessons? In the following list factors are identified by country, by way of illustration.

(1) The presence of economic and social forces strongly conducive to economic action; clearly a country that is not oriented to economic activity and the prospect of economic growth will be a poor host to collective bargaining; each country encompassed collective bargaining after it had started to «take off» in economic growth.

(2) Separation of labour from the ownership of capital, leading to a sedentary wage-oriented economy with a strong focus of common interest within the labour factor of production (cf. the United Kingdom in the 18 th century).

(3) Presence or absence of an indigenous labour movement; where are indigenous labour movement precedes collective bargaining, it will influence the development of the character and processes of collective bargaining (contrast the United Kingdom with Canada).

(4) Presence or absence of collective bargaining outside the framework of the law; where collective bargaining comes into existence extra-legally, the system will likely be autonomous, that is, shaped by non-legal forces and operating without legal sanctions other than the tolerance of the state (cf. United Kingdom).

(5) Condition of the general and the particular law respecting conventional trade union activity; where a trade union movement has to overcome legal obstacles to its legitimacy and the pursuit of its objectives, it will emerge militant and ucompromising in the assertion of its status as a significant social institution (compare the relevance to the development of the trade union movement of reforms in the United Kingdom, the United States and Canada).

(6) Attitude of employers to collective bargaining as public policy; where the attitude of employers to collective bargaining is hostile, the highest quality in the relationship between management and organized labour will likely be one of "antagonistic cooperation»; where the attitude is one of mutual dependence, one should expect a relationship of community of interest (cf. Sweden).

(7) Public attitude to collective bargaining as public policy; in the United Kingdom the public probably did not have a very clear awareness of 
and hence «attitude» to collective bargaining as unions went through the struggles of the 19th century, at least not an attitude of any appreciable focus, in spite of the drama of events in retrospect; the system just grew in its own way; in the United States, in contrast, an effective system of collective bargaining ultimately was imposed by a populist government against the opposition of the US Supreme Court in the midst of a world-wide depression, and its legalistic structure reflects its origin.

(8) Attitude of government and employers to labour participation in management; in West Germany, union participation in management is accepted as industrial policy by employers and as public policy by governments, and it leads to an acceptance of the philosophy of codetermination; in contrast, there is little receptivity to the concept in the United Kingdom, the United States and Canada.

(9) A labour movement geared to political activity, and a role for it in the political structure; where the labour movement has found a viable role within the political structure of the state, collective bargaining relationships appear to be more stable and the status of the labour movement more secure; a contrast may be made between the United Kingdom and the United States on one hand and Canada on the other.

(10) Presence or absence of strong traditions, conventions and attitudes amongst the participants, actual or potential; contending forces will ultimately produce their own direction and their own magnitude, as one can see in the contrast between the United Kingdom and the United States.

(11) General perception of the need for the institution of collective bargaining as an instrument of social ordering in an industrial society; clearly in the mid-1930's in the United States collective bargaining was widely recognized as a desirable instrument of social ordering; the overwhelming reelection of President Roosevelt in 1936 moderated the conservative stance of the US Supreme Court against the New Deal legislative program and led to the acceptance of the National Labour Relations Act as constitutional.

(12) Presence of an economic (and social and political) crisis or disaster in which collective bargaining is perceived to be a key instrument of recovery and stability; there is an element of high drama, if not desperation, in the circumstances in which Sweden and the United States acquired their respective systems, such as to leave no doubt as to what is public policy; the fire of commitment is lacking for the most part in Canada.

(13) Pressure to conform to an external (international) model; we are just beginning to experience and appraise the impact of the institutions of the European Community on the domestic institutions of member states; the European Community model for the business corporation reaches explicitly beyond the rights of directors, shareholders and creditors to the constituencies of employees and the public.

(14) Nature and level of international trade; for example, the forces of international competition are bound to have an impact on the results of collective bargaining and vice versa; costs of production will affect the 
exchange rate of domestic currency and hence the terms of collective bargaining, as will pressure for parity or comparability in rates of wages.

(15) Homogeneity or heterogeneity of the labour force; the labour forces in Canada and the United States are heterogeneous and the centrifugal forces of collective bargaining are enormous; the contrast with Sweden is obvious; both situations shape the tolerance of the collective bargaining systems.

(16) Employment levels and the nature of unemployment; high unemployment discourages collective bargaining, for there is a high level of "substitutability» in the labour force; at the same time, if collective bargaining as an instrument for the pursuit of social justice becomes dysfunctional, unfulfilled demands can be expected to express themselves in other ways, and where the unemployed encompass "high level manpower» the pool of potential leadership may be well stocked.

(17) Level of social welfare services and other maintenance schemes; where public social maintenance schemes provide a safety net against personal economic disaster, a load is removed from the collective bargaining system; it must be recognized that the observe is equally true.

(18) Nature, intensity and demographic levels of unfulfilled expectations; this factor involves the complex subject of population dynamics; it is in a sense a generalization of the preceding one. It relates, for example, to the distribution of the population by age among the youth and old age dependency groups with their peculiar expectations, and the economically productive group with its peculiar expectations; distribution between urban and rural communities and their peculiar mobilities and immobilities; levels of education and skills within the population; distribution within the configuration of the population of the employable unemployed. The greater the magnitude of expectations, the greater will be the pressures on all social institutions; as one of those institutions, collective bargaining may be broad as a camel's back, but there is a limit to the burden it can be expected to bear.

\section{REPRISE}

I return at last to restate the theme struck in the Introduction. Collective bargaining came to the industrialized democracies at different times and under different circumstances which produced different forms of system. Legal processes offer great variety of choice, and the choices, dictated by actualities, the events of the day, reinforce the appearance of disparity. But beneath the surface of those disparities may be identified the same basic issues of freedoms which are recognized and reconciled in the collective bargaining systems and which, in turn, depend for their sustenance on basic instruments of democratic governance. Free collective bargaining has known no other environment. 